early in his career at the Museum of issuing guides to the archæological collections, of which the first, on the Stone Age, appeared in 1902. Smith was mainly or solely responsible for the valuable guides, both in the original and in the revised editions, to the Stone, Bronze, and Iron Ages collections as well as to those of the Romano-British and Anglo-Saxon periods.

The preparation of these guides demanded an intimate and detailed knowledge and understanding of the characteristics of each individual specimen in the collections in relation to general typology as well as to the development of theoretical reconstruction in prehistoric and early historic studies. An even broader view was demanded in Smith's contribution of archæological chapters to early volumes of the "Victoria History of the Counties of England", which had commenced publication also early in Smith's career.

This thorough grounding in knowledge of the detailed evidence bearing upon British archæology proved of enormous service to scientific studies when Smith in 1908 joined the Council of the Society of Antiquaries of London, and afterwards became its honorary secretary and then its director, an office which he held for many years. Through the ramificatiors of the Society's many activities he was in close touch with archæological research in the field throughout Britain as well as on the Continent. Not only did he himself make many valuable contributions to archæological literature in its technical periodicalshis most considerable publication was an exhaustive illustrated catalogue of the Sturge collection of stone implements - but also he came to be widely recognized as, in a sense, a court of final appeal on the value and significance of any new discovery, or any fresh evidence bearing on previously ascertained facts in the prehistoric field of Britain. In the records of archæological discovery of the last twenty years, no name, with the possible exception of that of the Abbé Breuil, is more frequently quoted as responsible for an authoritative and final opinion than that of Reginald Smith.

\section{Mr. G. L. Bates}

Mr. G. L. BAtes, who died on January 31, was born in the State of Illinois in 1863 . He was the eldest son of a large family, and inherited his love of natural history from his mother. He was educated at Galesburg and Chicago, and it was his father's wish that he should enter the Church. However, he had a great desire to travel and study Nature, and he persuaded his father to send him to West Africa in 1895. His first years were spent in Gabon and the French Congo, and later he settled in the former German colony of Cameroon.

In 1896 Bates began to send collections to the British Museum, and up to 1928 there was a steady stream of specimens in all groups. Though primarily an ornithologist, Bates did not confine his collecting to birds, and he had the reputation as a very successful collector of reptiles, discovering some sixty-two new species, including Rana goliath and Trichobatrachus robustus, the curious hairy frog. In mammals, too, he made many discoveries, and his specimens of plants and fishes are models of careful collecting. From 1923 onwards he made many expeditions to different parts of West Africa, including a trip to the Southern Sahara, where he made some interesting observations on the affinities of the Saharan avifauna. Later he undertook the study of Arabian birds, and in 1934 paid a visit to Mr. H. St. J. Philby at Jedda.

Apart from his expeditions, Bates will always be remembered for his papers on the reversed underwing coverts of birds, and his study of the genus Smithornis. In this last he proved by anatomical evidence that the genus had nothing to do with the normal Passeres. This was confirmed later by P. R. Lowe, who demonstrated that the true position was in the Asiatic Eurylæmidæ. Perhaps Bates's most important contribution to ornithology was on the "Geographical Variation within the Limits of West Africa", in which he showed that these variations, whether in colour or size, fall within certain rules. In 1930 he published a useful little "Handbook of the Birds of West Africa".

Bates's shy and retiring nature was increased by long residence alone, but nevertheless, no one was more ready to help others, and he will be missed by many. In the late autumn he underwent a serious operation from which he never fully recovered.

\section{N. B. KINNEAR.}

\section{Prof. Fritz de Quervain}

Prof. Fritz de Quervarn, an eminent Swiss surgeon, who died last month at the age of seventyone years, was born at Sion, the capital of the Valais Canton, on May 4, 1868. He received his medical education in Bern, where he was assistant to Kronecker the physiologist from 1889 until 1891 and to Langhans the pathologist from 1891 until 1892, when he qualified. For the next two years he was assistant in Kocher's surgical clinic, and then entered on a surgical practice at Chaux-de-Fonds, where he became director of the surgical clinic in 1897. In 1902 he returned to Bern, where he remained until 1909 , when he was appointed professor of surgery in the Basle faculty of medicine, and finally in 1918 occupied the corresponding chair at Bern.

\section{WE regret to announce the following deaths:}

Lieut.-Colonel J. A. Amyot, C.M.G., lately Canadian deputy minister of pensions and national health, formerly professor of hygiene in the University of Toronto, aged seventy-two years.

Colonel R. E. B. Crompton, C.B., F.R.S., a pioneer in electrical engineering and mechanical road traction, on February 15, aged ninety-four years.

Mr. H. G. Newth, lecturer in zoology in the University of Birmingham, on February 17.

Prof. C. Tangl, director of the Institute of Experimental Physics, University of Budapest, on December 10 , aged seventy-one years. 